\title{
BIOMASS ALLOCATION TO ANCHORING STRUCTURES IN THE AQUATIC MACROPHYTES FROM THE SUBCONTINENTAL AND ATLANTIC CLIMATES IN EUROPE
}

\author{
JÓZEF SZMEJA ${ }^{1}$, BERNARD CLÉMENT ${ }^{2}$, KATARZYNA BOCIĄG ${ }^{1}$, \\ AGNIESZKA GAŁKA ${ }^{1}$, PIOTR SKURZYŃSKI ${ }^{1}$ \\ ${ }^{1}$ Department of Plant Ecology, University of Gdańsk \\ Al. Legionów 9, 80-441 Gdańsk, Poland \\ e-mail: biojs@univ.gda.pl \\ 2 UMR CNRS 6553 "Ecobio", Université de Rennes I \\ Campus de Beaulieu, F-35042 Rennes Cedex, France
}

(Received: December 5, 2006. Accepted: April 10, 2007)

\begin{abstract}
Biomass allocation to anchoring structures in 10 species of aquatic macrophytes in two types of the cool and humid temperate climate in Europe, subcontionental (NW Poland) and Atlantic (W France), was examined. The study focused on the weight of anchoring organs in Chara delicatula Ag., Ch. fragilis Desv., Juncus bulbosus L., Littorella uniflora (L.) Asch., Luronium natans (L.) Raf., Potamogeton pectinatus L., P. perfoliatus L., P. natans L. and Ranunculus fluitans (Lam.) Wimm., as well as submerged structures in Hydrocharis morsus-ranae L. The plants were collected from 10 geographically distant lakes and 2 rivers with a current velocity of $0.3-0.5 \mathrm{~m} \mathrm{~s}^{-1}$. It was assumed that biomass allocation to anchoring structures in rooting macrophytes depends on the time that mechanical forces, which can remove the plants from the occupied area, exert their effect.

It was found that, in the Atlantic and subcontinental climates, the ratio between the biomass of underground (or submerged) and above-ground structures (U/A index), calculated for the ramets of Chara fragilis, Hydrocharis morsus-ranae and Ranunculus fluitans, has similar values ( $\mathrm{p}>0.05$ ). Nevertheless, among seven species of Cormophyta, which were anchored in the lake or pond littoral, six (Juncus bulbosus, Littorella uniflora, Luronium natans, Potamogeton pectinatus, $P$. perfoliatus and $P$. natans) had higher values of the U/A index in the Atlantic climate than in the subcontinental type $(\mathrm{p}<0.05)$. This can be explained by the lack of ice cover and, consequently, a longer time of wave action than in the subcontinental climate.
\end{abstract}

KEY WORDS: aquatic plants, allocation, anchoring structures, climate.

\section{INTRODUCTION}

Populations of inland macrophytes, as well as water bodies in which they occur, have a scattered, island-like (discontinuous) distribution in each dimension of geographical space (local, regional or continental). What is more, geographical ranges of most aquatic plants are broad and generally cover a few climatic zones (Sculthorpe 1967; Walter and Straka 1970; Hutchinson 1975; Walter et al. 1975; Hultén and Fries 1986). Without doubt there are many causes of such distribution. According to Santamaría (2002), a limited effect of the climate itself can be one of them. This is an interesting viewpoint, but it has not been definitively proven yet. The fact that the results of the climate effect are visible mainly in the disjunctions at the junction of major climate types, that is tropical, temperate and subarctic (op. cit.), is not a persuasive evidence for the legitimacy of this claim.
Geographical ranges are a synthetic and static picture of taxon distribution and result from the application of cartographic analyses of vast expanses of land (Walter et al. 1975). The term 'climate' is very general and, as a result, of little use in detailed ecological or phytogeographical analyses, such as determination of plants' life history, their plastic responses or causes of the variability of the inner structure of their ranges for example. It is more advantageous to refer to climate components, for instance long-term mean temperature, than to a climate type or its regional differences. Water itself additionally complicates the determination of the influence of climate on organisms, as it reduces the effect of air temperature fluctuations on land (Bowers 1987). Furthermore, water periodically changes its state of matter even in the same climate type. We think that, in the cool and humid temperate climate, it is not only temperature as a climate component but also its derivatives, for example the average length of ice-cover periods 
over the year, that generate changes in plants, which can lead to permanent modifications of their morphology in the long term.

Since aquatic plant populations are distributed in an island-like way, and the climate, through both direct and indirect effect, differentiates such 'islands,' the inner structure of a range resembles, to put it graphically, a Persian carpet. Its intricate pattern is the outcome of adaptation in regional populations, while its rich colours result from plastic responses in local populations. In the subcontinental temperate climate, biomass allocation to underground organs in order to maintain the occupied area is one of significant adaptations of aquatic macrophytes (Szmeja and Gałka 2008). We put forward the hypothesis that such a plant adaptation will be also found in distant populations from the Atlantic climate. We assume that in rooting aquatic macrophytes biomass allocation to anchoring structures is regulated by the length of periods of ice-cover on water bodies. The longer the ice-cover remains, the shorter the time that wind-induced wave action and hydrodynamic forces, which can remove vegetation from the occupied area, affect plants.

\section{METHODS}

We studied biomass allocation to anchoring structures (holdfasts, roots, rhizomes and stolons) in 10 species of aquatic macrophytes, including 9 which have contact with the substrate (Chara delicatula Ag., Ch. fragilis Desv., Juncus bulbosus L., Littorella uniflora (L.) Asch., Luronium natans (L.) Raf., Potamogeton pectinatus L., P. perfoliatus L., P. natans L., and Ranunculus fluitans (Lam.) Wimm.) and one pleustophyte (Hydrocharis morsus-ranae L.). According to the classification of the Earth's climates suggested for biogeographical analyses by Walter et al.
(1975), the plants were collected from two types of the cool and humid temperate climate: (1) subcontinental ( 9 species from 6 lakes and one species from a river in NW Poland, region of Pomerania); and (2) marine (NW France), that is thermally milder, hereafter called 'Atlantic' ( 8 species from 4 ponds and shallow lakes in Brittany and 2 species in the region of Brenne: $P$. natans from a pond and $R$. fluitans from a river). The samples from Pomerania were collected in 2005, whereas the ones from Brittany in 2006. The names of water bodies in which plants were gathered are given in Table 1 .

The study focused on the weight of shoot (or thallus) with an adjoining anchoring structure. The term 'ramet' was used for this structural unit of an individual. Fifty mature ramets of each species were collected in Poland, and thirty in France (800 ramets in total). Ramet height (or length) was measured, and then each ramet was divided into the above-ground and underground (anchoring) part (Hydrocharis was an exception with the underwater part stabilizing buoyancy). The plants were dried to constant weight and weighed. The ratio between the underground dry weight (roots, holdfasts, rhizome or stolon parts) and the above-ground one (stem and leaves) is the comparative measure of biomass allocation to anchoring structures in ramets (U/A index). The significance of differences between the arithmetic means of plant features was tested using ANOVA, Kruskal-Wallis test (Łomnicki 1999), for $\mathrm{p}<0.05$.

Owing to the proposed research hypothesis, which assumes that the length of ice-cover periods on water bodies affects biomass allocation to anchoring structures in macrophytes, the evaluation of local aquatic environment conditions was limited to the following features (Table 1): $\mathrm{pH}$, conductivity $\left[\mu \mathrm{S} \mathrm{cm} \mathrm{cm}^{-1}\right]$ and water flow velocity $\left[\mathrm{m} \mathrm{s}^{-1}\right]$. Conductivity was measured by means of an LF 95 analyser with a Tetra Con 96 electrode, $\mathrm{pH}$ using a 320 SET $1 \mathrm{pH}$ -

TABLE 1. Environmental conditions of aquatic macrophyte occurrence.

\begin{tabular}{|c|c|c|}
\hline Feature & Pomerania & Brittany, Brenne \\
\hline Mean long-term air temperature $\left[{ }^{\circ} \mathrm{C}\right]$ & $6.4-6.8$ & $11.2-11.5$ \\
\hline Number of days in a year with temperatures above $0^{\circ} \mathrm{C}$ & 275 & 365 \\
\hline Mean number of days with ice-cover & 100 & 0 \\
\hline Głęboczko (Chara delicatula) & $7.8 / 97$ & - \\
\hline Druzno (Hydrocharis morsus-ranae) & $7.9 / 442$ & - \\
\hline Krasne (Juncus bulbosus, Littorella, Luronium) & $4.5 / 48$ & - \\
\hline Ostrowite (Potamogeton pectinatus, Chara fragilis) & $8.2 / 219$ & - \\
\hline Dybrzk (Potamogeton perfoliatus) & $7.9 / 257$ & - \\
\hline Nawionek (Potamogeton natans) & $7.6 / 55$ & - \\
\hline Er Varquez (Juncus, Chara delicatula, Ch. fragilis) & - & $8.4 / 885$ \\
\hline Apigne (Potamogeton pectinatus, $P$. perfoliatus) & - & $9.2 / 457$ \\
\hline Gannedel (Hydrocharis, Potamogeton natans) & - & $6.5 / 230$ \\
\hline \multicolumn{3}{|l|}{ River flow $\left[\mathrm{cm} \mathrm{s}^{-1}\right]$} \\
\hline Brda (Ranunculus fluitans) & 0.3 & - \\
\hline Indre (Ranunculus) & - & 0.5 \\
\hline \multicolumn{3}{|l|}{ Water $\mathrm{pH} /$ conductivity $\left[\mu \mathrm{cm}^{-1} ; 20^{\circ} \mathrm{C}\right]$ in rivers } \\
\hline Brda (Ranunculus) & $7.4 / 310$ & - \\
\hline Indre (Ranunculus) & - & $7.7 / 517$ \\
\hline
\end{tabular}


-meter, and flow velocity in rivers and wave velocity in lakes and ponds were determined on the basis of the arithmetic mean from three measurements performed on a one-off basis using a Nautilus C 2000 Sensor flow meter. Such climate features as mean long-term air temperature $\left[0^{\circ} \mathrm{C}\right]$, number of days with temperatures above $0^{\circ} \mathrm{C}$ in a year and the average number of days with ice cover in a year were taken from the following sources: Walter and Lieth (1967), Walter et al. (1975), Choiński (1995), Chauris and Hallégouët (2003) and Clément et al. (2003).

\section{RESULTS}

\section{Environmental conditions}

In both types of the cool and humid temperate climate, that is subcontinental and Atlantic, the studied plants occurred in a wide range of aquatic environments which differed in terms of many features including water $\mathrm{pH}$ and conductivity (Table 1) and, undoubtedly, also oxygenation, concentration of biogenic substances, thermal conditions, lighting, morphometry of water bodies, substrate granulation, availability of carbon forms needed for photosynthesis and activity of microorganisms. According to the formulated hypothesis, however, it is not only these factors, but also climate and its derivatives, that are responsible for the emergence of certain adaptations of aquatic plants.

In north-west Poland, the mean long-term air temperature ranges from 6.4 to $6.8^{\circ} \mathrm{C}$. Temperatures above zero generally continue for 275 days a year, while sub-zero temperatures for around 90 days (Walter and Lieth 1967). Owing to the ice cover, wind-induced wave action does not occur for about 100 days, that is 0.27 of a year. On the other hand, the climate is milder in western France, especially in Brittany (Chauris and Hallégouët 2003; Clément et al. 2003). The mean long-term air temperature is 11.2$11.5^{\circ} \mathrm{C}$ (Walter and Lieth 1967), and ice cover does not form in general (Table 1). In western France, the ice-free period on water bodies is on average 1/4 longer than in north-west Poland.

\section{Biomass allocation}

Chara delicatula: in the population from Pomerania, herafter called 'the first', the plant grows to a height of $39.1 \pm 10.7 \mathrm{~cm}$. An individual weighs $0.05 \pm 0.03 \mathrm{~g} \mathrm{~d}$.w. (Fig. 1 ), its above-ground parts $0.04 \pm 0.02 \mathrm{~g} \mathrm{~d}$.w., and its underground parts $0.01 \pm 0.006 \mathrm{~g}$ d.w. This means that $22.7 \%$ of biomass is located in the substrate and serves the anchoring function. The ratio between underground and above-ground biomass (U/A index calculated for $\mathrm{n}=50$ individuals) amounts to $0.36 \pm 0.17$ (Fig. 2). On the other hand, in the population from Brittany, hereafter called 'the second', the plant reaches $9.4 \pm 3.1 \mathrm{~cm}$ and weighs $0.02 \pm 0.02 \mathrm{~g} \mathrm{~d} . \mathrm{w}$. Its above-ground and underground parts constitute $95.2 \%$ $(0.016 \pm 0.02 \mathrm{~g} \mathrm{d.w.})$ and $4.8 \%(0.0008 \pm 0.0001 \mathrm{~g} \mathrm{d.w.})$ of this weight, respectively. The U/A index for $n=30$ individuals was calculated at $0.19 \pm 0.07$, which means that its value in Brittany is lower than in the population from Pomerania. The difference between the compared populations is significant $(\mathrm{p}<0.05)$.

Chara fragilis (Figs 1 and 2): in the first population the plant is $54.7 \pm 10.4 \mathrm{~cm}$ high. The individual weighs $0.17 \pm 0.07 \mathrm{~g} \mathrm{~d}$.w., and its above-ground and underground parts have a weight of $0.14 \pm 0.05 \mathrm{~g} \mathrm{d.w.} \mathrm{(92.4 \% )} \mathrm{and}$ $0.03 \pm 0.02 \mathrm{~g} \mathrm{~d} . \mathrm{w}$. (7.6\%), respectively. The U/A index $(\mathrm{n}=50$ individuals) is $0.23 \pm 0.12$. In the second population the plant reaches $34.6 \pm 13.4 \mathrm{~cm}$. The individual weights $0.08 \pm 0.07 \mathrm{~g} \mathrm{~d}$.w. Its above-ground parts constitute $94.1 \%$ $(0.074 \pm 0.07 \mathrm{~g} \mathrm{d.w.})$ and underground parts $5.9 \%$ $(0.0046 \pm 0.003 \mathrm{~g} \mathrm{d.w.})$. The U/A index for individuals was calculated at $0.22 \pm 0.13$, which means that its value is similar to the one in the population from Pomerania. The difference between the compared populations is statistically insignificant $(\mathrm{p}=0.39)$.

Hydrocharis morsus-ranae (Figs 1 and 2): in the first population the ramet weighs $0.61 \pm 0.29 \mathrm{~g}$ d.w. Its floating structures (leaves and inflorescences) have a weight of $0.34 \pm 0.19$ g d.w. $(60.6 \%)$, and underwater (leaves and stolons) $0.24 \pm 0.14 \mathrm{~g} \mathrm{d.w}$. (39.4\%). The ratio between the biomass of underground and above-ground structures (U/A) was calculated for $n=50$ ramets at $0.64 \pm 0.19$. In the second population ramets are lighter $(0.14 \pm 0.05 \mathrm{~g} \mathrm{~d} . \mathrm{w}$.). Floating structures constitute $64.3 \%(0.09 \pm 0.04 \mathrm{~g} \mathrm{~d} . \mathrm{w}$.$) , while$ underwater structures $35.7 \%(0.05 \pm 0.02 \mathrm{~g} \mathrm{~d} . \mathrm{w}$.) of the whole weight. The U/A index $(n=30)$ has a value of $0.58 \pm 0.31$. The difference between the compared populations is statistically insignificant ( $\mathrm{p}>0.05)$.

Juncus bulbosus (Figs 1 and 2): in the first population the individual weighs $0.32 \pm 0.23 \mathrm{~g} \mathrm{~d} . \mathrm{w}$. The above-ground organs have a weight of $0.23 \pm 0.16 \mathrm{~g} \mathrm{d.w}$. (71.9\%), and the underground ones $0.09 \pm 0.03 \mathrm{~g}$ d.w. $(28.1 \%)$. The U/A in$\operatorname{dex}(\mathrm{n}=50$ ramets) has a value of $0.39 \pm 0.09$. In the second population the individual is heavier $(0.49 \pm 0.28 \mathrm{~g} \mathrm{~d} . \mathrm{w}$.) than in the first one $(\mathrm{p}<0.05)$. The ratio between underground and above-ground structures (U/A index) is $0.50 \pm 0.16$, which means that it is higher in the population from Brittany than in the one from Pomerania $(\mathrm{p}=0.008)$.

Littorella uniflora (Figs 1 and 2): in the first population the ramet's weight is $0.12 \pm 0.10 \mathrm{~g} \mathrm{~d} . \mathrm{w}$. The above-ground and underground organs weigh $0.08 \pm 0.04 \mathrm{~g} \mathrm{d.w.}(66.7 \%)$ and $0.04 \pm 0.02 \mathrm{~g}$ d.w. (33.3\%), respectively. The U/A index $(n=125$ ramets) was calculated at $0.57 \pm 0.1$. In the second population the ramet has a weight of $0.07 \pm 0.03 \mathrm{~g} \mathrm{~d} . w$. The above-ground organs weigh $0.04 \pm 0.02 \mathrm{~g} \mathrm{d.w}$. (57.1\%) and underground parts $0.03 \pm 0.01 \mathrm{~g} \mathrm{d.w.}(42.9 \%)$. The U/A in$\operatorname{dex}(n=30$ ramets $)$ amounts to $0.62 \pm 0.10$, that is its value in the population from Brittany is higher than in the one from Pomarania $(\mathrm{p}<0.05)$.

Luronium natans (Figs 1 and 2): in the first population the ramet's weighs $0.09 \pm 0.03 \mathrm{~g}$ d.w. The above-ground organs have a weight of $0.07 \pm 0.02 \mathrm{~g} \mathrm{d.w}$. (77.8\%) and underground ones $0.02 \pm 0.01 \mathrm{~g} \mathrm{d.w}$. (22.2\%). The ratio between the biomass of underground and above-ground structures (U/A, $\mathrm{n}=150$ ramets) has a value of $0.25 \pm 0.06$. In the second population the ramet weighs $0.07 \pm 0.03$ $\mathrm{g}$ d.w. The above-ground and underground organs constitute $63.6 \%(0.04 \pm 0.02 \mathrm{~g} \mathrm{d.w.})$ and $36.4 \%(0.02 \pm 0.01)$, respectively. The U/A index ( $\mathrm{n}=30$ ramets) is $0.39 \pm 0.08$, which means that it is higher than in the population from Pomerania. The difference between the compared populations is highly significant $(\mathrm{p}<0.001)$.

Potamogeton pectinatus (Figs 1 and 2): in the first population the plant grows to $36.2 \pm 15.6 \mathrm{~cm}$ and has a weight of $0.18 \pm 0.11 \mathrm{~g} \mathrm{~d} . \mathrm{w}$. The above-ground organs contain $88.9 \%$ of its biomass, while the underground structures (rhizome and roots) $11.1 \%$. The U/A index for ramets $(n=50)$ was 


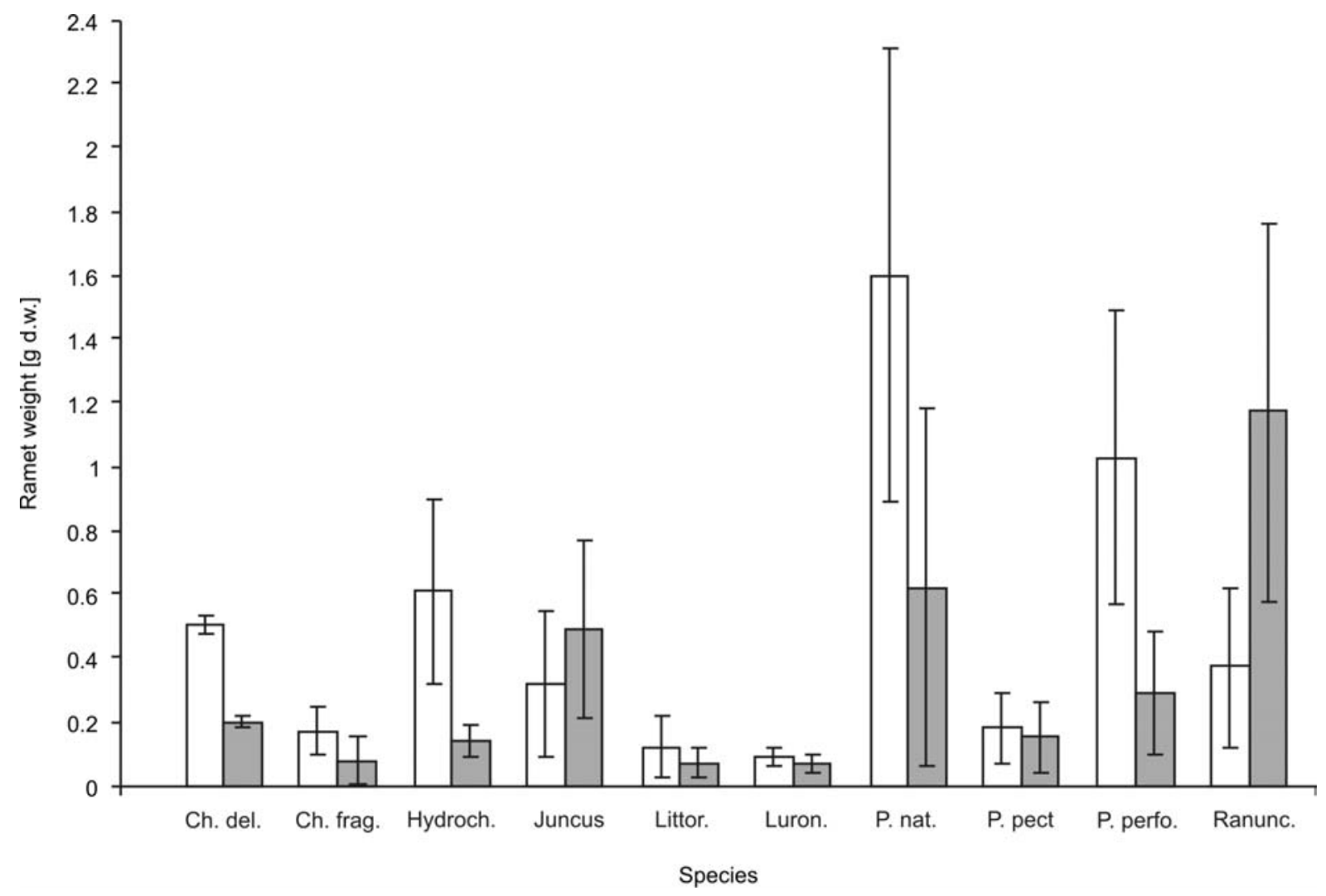

Fig. 1. Weight of ramets [g d.w.] of aquatic macrophytes from the subcontinental (white bars) and Atlantic (lined bars) types of the cool and humid temperate climate of Europe.

Species: Chara delicatula*, Ch. fragilis, Hydrocharis morsus-ranae, Juncus bulbosus, Littorella uniflora, Luronium natans, Potamogeton natans, P. pectinatus, $P$. perfoliatus and Ranunculus fluitans.

Explanations: $* \times 10^{1}$

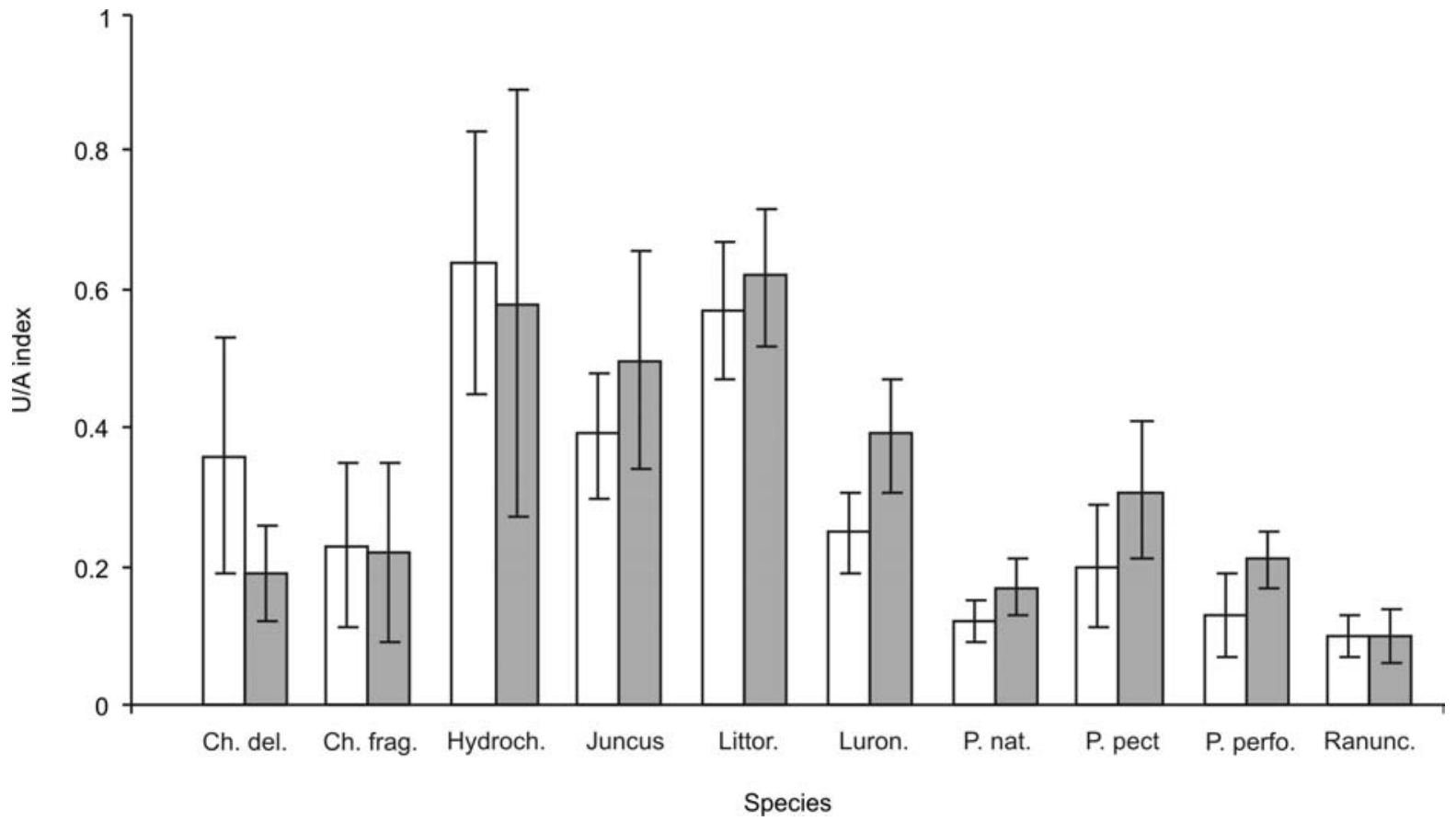

Fig. 2. Biomass ratio between underground and above-ground structures (U/A index) in the ramets of aquatic macrophytes from the subcontinental (white bars) and Atlantic (lined bars) types of the cool and humid temperate climate of Europe.

Species: Chara delicatula, Ch. fragilis, Hydrocharis morsus-ranae, Juncus bulbosus, Littorella uniflora, Luronium natans, Potamogeton natans, P. pectinatus, P. perfoliatus and Ranunculus fluitans. 
calculated at $0.20 \pm 0.09$. In the second population the plant is $93.9 \pm 39.2 \mathrm{~cm}$ high and weighs $0.15 \pm 0.11 \mathrm{~g} \mathrm{~d} . \mathrm{w}$. The above-ground organs contain $0.13 \pm 0.11 \mathrm{~g} \mathrm{~d}$.w. (86.7\%) of its biomass, whereas the underground structures $0.02 \pm 0.007(13.3 \%)$. The ratio between underground and above-ground structures (U/A index, $n=30$ ramets) is $0.31 \pm 0.10$. Thus in the population from Brittany it is higher than in the one from Pomerania. The difference between the compared populations is highly significant $(\mathrm{p}=0.009)$.

Potamogeton perfoliatus (Figs 1 and 2): in the first population the plant grows to a height of $84.8 \pm 21.8 \mathrm{~cm}$ and weight of $1.03 \pm 0.46 \mathrm{~g} \mathrm{~d}$.w. The above-ground organs weigh $0.92 \pm 0.51 \mathrm{~g} \mathrm{~d} . w .(89.3 \%)$, while the underground structures $0.11 \pm 0.07 \mathrm{~g}$ d.w. $(10.7 \%)$. The U/A index $(\mathrm{n}=50$ ramets) is $0.13 \pm 0.06$. In the second population the plant reaches $26.2 \pm 13.0 \mathrm{~cm}$ and weighs $0.29 \pm 0.19 \mathrm{~g} \mathrm{~d} . \mathrm{w}$. Its aboveground organs have a weight of $0.25 \pm 0.18 \mathrm{~g} \mathrm{d.w}$. (85.3\%), and underground structures $0.04 \pm 0.02 \mathrm{~g} \mathrm{d.w}$. (14.7\%). The U/A index ( $n=30$ ramets) amounts to $0.21 \pm 0.04$, which means that in the population from Brittany its value is much higher than in the one from Pomerania $(\mathrm{p}<0.0001)$.

Potamogeton natans (Figs 1 and 2): in the first population the plant is $173.4 \pm 29.9 \mathrm{~cm}$ high and weighs $1.6 \pm 0.7$ g d.w. Its above-ground organs contain $1.38 \pm 0.92 \mathrm{~g} \mathrm{~d} . w$. $(86.3 \%)$, while the underground parts $0.22 \pm 0.16 \mathrm{~g} \mathrm{~d} . \mathrm{w}$. $(13.7 \%)$. The ratio between the biomass of underground and above-ground structures (U/A index, $n=30$ ramets) is $0.12 \pm 0.03$. In the second population the plant reaches $48.7 \pm 11.4 \mathrm{~cm}$, and its weight amounts to $0.62 \pm 0.56 \mathrm{~g} \mathrm{~d} . \mathrm{w}$. The above-ground organs constitute $79.0 \%(0.49 \pm 0.47$ g d.w.), and the underground structures $21.0 \%(0.12 \pm 0.05$ $\mathrm{g}$ d.w.). The value of the U/A index ( $\mathrm{n}=30$ ramets) is $0.17 \pm 0.04$, which means that in the population from Brittany it is higher than in the one from Pomerania. The difference between the compared populations is highly significant $(\mathrm{p}<0.00001)$.

Ranunculus fluitans (Figs 1 and 2): in the first population the ramets are $32.8 \pm 10.7 \mathrm{~cm}$ long and weigh $0.37 \pm 0.25$ $\mathrm{g}$ d.w. Their anchoring structures represent $9.3 \%$ $(0.034 \pm 0.02 \mathrm{~g} \mathrm{~d} . w$.$) . The ratio between the biomass of$ underground and above-ground structures (U/A, n=30 ramets) was calculated at $0.10 \pm 0.04$ (median 0,$099 ; 75 \%$ of cases have the value of $0,10 \mathrm{~g} \mathrm{d.w.).} \mathrm{In} \mathrm{the} \mathrm{second} \mathrm{popula-}$ tion the ramets are $93.9 \pm 29.9 \mathrm{~cm}$ long and weigh $1.17 \pm 0.59$ $\mathrm{g}$ d.w. Their anchoring structures constitute 8,5\% (0.10 $\pm 0,03$ $\mathrm{g}$ d.w.). The U/A index ( $\mathrm{n}=30$ ramets) is $0.10 \pm 0.03$ (median 0,$099 ; 75 \%$ of cases weigh $0,13 \mathrm{~g} \mathrm{~d}$.w.). The compared populations do not differ in terms of this feature $(\mathrm{p}=0.23)$. It should be mentioned, though, that in the population from France as many as $75 \%$ of cases have a higher value of the U/A index than in the Polish population (0.13 compared to $0.10)$. The plant flowers in both populations.

\section{SUMMARY}

1. Out of seven aquatic species of Cormophyta which anchor themselves in the littoral zone of lakes or ponds, six (Juncus bulbosus, Littorella uniflora, Luronium natans, Potamogeton pectinatus, $P$. perfoliatus and $P$. natans) have higher biomass ratios between underground and above-ground structures (U/A index) in the Atlantic climate than in the subcontinental type (Fig. 2).
2. Three species, Hydrocharis morsus-ranae (floating, without anchoring structures), Chara fragilis (primarily aquatic) and Ranunculus fluitans (typically riparian) have similar U/A index values in both climate types (Fig. 2); the last two plants occurred in conditions dominated by one environmental factor.

3. On the basis of the collected data it is impossible to decide if in primitive hydrophytes, represented by two species of Chara, biomass allocation to anchoring structures changes in both climate types as it does in Cormophyta. It is recommended that the research is continued on a greater number of species from this plant group.

\section{DISCUSSION}

Water has a high specific heat, low heat conduction and accumulates much heat. Yet it releases the heat slowly. As a consequence, the aquatic environment protects macrophytes against temperature fluctuations. That is why it is not an easy task to determine the effect of temperature as a climatic factor on aquatic plants in their natural environment. It can be assumed, however, that submerged macrophytes are susceptible to temperature fluctuations, as their surface is devoid of a heat-insulating layer. Their metabolic and phenological responses prove this assumption (Hutchinson 1975; Szmeja 1994a; Wetzel 2001). Nevertheless, such reactions do not lead to changes in biomass allocation for example, which means that they do not transform the plants. This fact does not facilitate the evaluation of the direct climate effect either.

The studies to date indicate that temperature affects the phenology of local populations (Phillips et al. 1983; Szmeja and Bazydło 2005) and the course of physiological reactions (Santamaría and van Vierssen 1997; Pilon and Santamaría 2002). It is worth mentioning, however, that submerged macrophytes have varied thermal preferences: most have a high thermal optimum, but a certain group, isoetids for instance, maintain a high rate of photosynthesis also at a low temperature (Boylen and Sheldon 1976). Such division of species into thermally different environments suggests that, according to the theory of natural selection, temperature, as a component of climate, may be a contributing factor in the selection and speciation of aquatic plants.

The in vivo studies on populations of submerged macrophytes focus on the cause and effect relations in the spatial microscale (e.g. Barko and Smart 1986; Duarte and Kalf 1990; Szmeja 1994a; Keddy et al. 2001; Heegaard et al. 2001; Szmeja and Bociąg 2004), and much less frequently on comparative analyses of such relations in the macroscale, for example in geographically distant populations from the same climate or from different climatic zones (Phillips et al. 1983; Jacobsen and Terneusb 2001; Santamaría and García 2004). Comparative studies of aquatic macrophytes in the macroscale could become a source of information on the effect of climate in general or its secondary effect on life strategies and evolution of this plant group.

The aquatic environment facilitates the studies on the morphological responses and life history of macrophytes in a number of ways. This is a consequence of the properties of water itself, which is 775 times denser than air and 100 times as viscous, due to which the mechanical effect of water is much greater than that of air, especially when water 
is in motion (Szmeja 2006). What is more, depending on temperature, which is a significant climate feature, water is either a fluid or a solid (ice). In the subcontinental type of temperate climate, which occurs in north-west Poland, the mean long-term air temperature ranges from 6.4 to $6.8^{\circ} \mathrm{C}$, sub-zero temperatures most often last about 90 days a year (Walter and Lieth 1967), and the ice cover which forms on the surface of water bodies remains there for nearly 100 days. This means that the wind-induced waves fade out and mechanical disturbances, which can remove shallow-water macrophytes from occupied areas, are stopped for 0.27 of a year. On the other hand, in the Atlantic type of temperate climate, which occurs in western France, especially in Brittany, the climate is milder (Chauris and Hallégouët 2003, Clément et al. 2003), and as a result, the ice cover generally does not form (Table 1). In the Atlantic climate the wind-induced wave pressure on growing aquatic plants lasts a quarter of a year longer than in the subcontinental type. In climatology, the length of ice-cover periods is not a feature of climate but its derivative. In ecology, the effect of this derivative on shallow-water aquatic plants is associated with either frost damage (Pearsall 1920; Hutchinson 1975 ) or the inhibition of the wind-induced wave pressure (Keddy 1985; Szmeja 1994b).

Our studies indicate that six aquatic species of Cormophyta out of seven had a higher U/A index (biomass ratio between underground and above-ground structures) in the Atlantic type of temperate climate than in the subcontinental type. Distinct differences were found in evergreen isoetids (Juncus bulbosus, Littorella uniflora, Luronium natans), that is the isoetids which stay in contact with the environment longer in a year than aquatic macrophytes, which winter in the form of perennation organs. However, such differences were not recorded in plants without anchoring structures (floating Hydrocharis morsus-ranae). It is interesting to note that they were not observed in the typically riparian Ranunculus fluitans either (Fig. 2), a species which occurs in both climate types in rivers with a similar flow velocity $\left(0.3-0.5 \mathrm{~m} \mathrm{~s}^{-1}\right)$, that is in the environments with a comparable effect of hydrodynamic forces.

The wave pressure on plants growing in shallow water is a factor stimulating the transfer of additional biomass to underground organs (Szmeja and Gałka 2008). It is worth mentioning that the majority of aquatic macrophytes have a clonal structure, that is they are composed of ramets, which serve similar (repetitive) functions in a clone: for example each of them plays a role in the anchoring of a plant. In an individual with such a structure, the anchoring success depends on the number of ramets, their ability to attach themselves to the substrate, and substrate compaction. Since the structure of the substrate is unrelated to climate, like the number of ramets, which is a derivative of a clone's age and architecture, the anchoring of a plant depends especially on the ability of ramets to attach themselves to the substrate. Additional biomass allocation to underground anchoring structures enhances the plant's adherence to the substrate, which in turn increases the probability of its survival and maintenance of the occupied area (Szmeja 1994a).

All in all, the similar response in most of the studied Cormophyta, which were collected from various water bodies in two climate types, is not accidental. It can be concluded from this response that such environmental factors as lighting or chemical and physical water properties play a secondary role here. The strengthening of anchoring structures is probably a way of plants' defense against the pressure exerted by hydrodynamic forces, which can root them out of the substrate.

\section{ACKNOWLEDGEMENTS}

The authors would like to thank Mr François Pinet for organizing the work in Parc Naturel Régional de la Brenne, Ms Mireille Clément and Ms Krystyna Szmeja for their help in field work and Ms Emilia Bochenek for translating this text into English. The study was done within the framework of the project 2 P04G 00127 financed by the State Committee for Scientific Research and the Initiative European Support funded by the Bretagne Council - France leans against the EUROLIMPACS project GOCE-CT-2003505540 of the European Union.

\section{LITERATURE CITED}

BARKO J.W., SMART R.M. 1986. Sediment-related mechanisms of growth limitation in submersed macrophytes. Ecology 67: $1329-1340$.

BOWES G. 1987. Aquatic plant photosynthesis: strategies that enhance carbon gain. In: Plant Life in Aquatic and Amphibious Habitats. Crawford R.M.M. (ed.). Blackwell Scientific Publications, Oxford, pp. 79-98.

BOYLEN C.W., SHELDON R.B. 1976. Submergent macrophytes: growth under winter ice cover. Science 194: 841-842.

CHAURIS L., HALLÉGOUËT B. 2003. Géologie et géographie. In: La Bretagne (la géologie, les milieux, la faune, la flore, les hommes). La bibliothčque du naturaliste. F. de Beaulieu (ed.). Delachaux \& Niestlé, Paris, pp. 7-52.

CHOIŃSKI A. 1995. An outline of the physical limnology of Poland. Wyd. Naukowe UAM, Poznań (in Polish).

CLÉMENT B., MAGNANON S., HOLDER E., LE DOARÉ J. 2003. Milieux terrestres et aquatiques. In: La Bretagne (la géologie, les milieux, la faune, la flore, les hommes). La bibliothèque du naturaliste. F. de Beaulieu (ed.). Delachaux \& Niestlé, Paris, pp. 53-124.

DUARTE C.M., KALFF J. 1990. Patterns in the submerged macrophyte biomass of lakes and the importance of the scale of analysis in the interpretation. Can. J. Fish. Aquat. Sci. 43: 1900-1908.

HEEGAARD E., BIRKS H.H., GIBSON C.E., SMITH S.J., WOLFE-MURPHY S. 2001. Species-environmental relationships of aquatic macrophytes in Northern Ireland. Aquat. Bot. 70: $175-223$.

HULTÉN E., FRIES M. 1986. Atlas of north Europaean vascular plants north of the tropic of Cancer. I, II, III. Koeltz Sci. Books, Königstein.

HUTCHINSON G.E. 1975. A Treatise of Limnology. John Wiley \& Sons, New York.

JACOBSEN D., TERNEUSB E. 2001. Aquatic macrophytes in cool aseasonal and seasonal streams: a comparison between Ecuadorian highland and Danish lowland streams. Aquat. Bot. 71: 281-295.

KEDDY P.A. 1985. Wave disturbance on lakeshores, and the within-lake distribution of Ontario's Atlantic Coastal Plain Flora. Can. J. Bot. 63: 66-660.

KEDDY P., GAUDET C., FRASER L.H. 2001. Effects of low and high nutrients on the competitive hierarchy of 26 shoreline plants. J. Ecol. 88: 413-423.

ŁOMNICKI A. 1999. Introduction to statistics for naturalists. Wyd. Nauk. PWN, Warszawa (in Polish). 
PEARSALL W.M. 1920. The aquatic vegetation of English lakes. J. Ecol. 8: 163-201.

PHILLIPS R.C., MCMILLAN C., BRIDGES K.W. 1983. Phenology of eelgrass, Zostera marina L., along latitudinal gradients in North America. Aquat. Bot. 15: 145-156.

PILON J.J., SANTAMARÍA L. 2002. Clonal variation in the thermal response of the submerged aquatic macrophyte Potamogeton pectinatus. J. Ecol. 90: 141-152.

SANTAMARÍA L., VAN VIERSSEN W. 1997. Photosynthetic temperature responses of fresh- and brackish-water macrophytes: a review. Aquat. Bot. 58: 135-150.

SANTAMARÍA L., GARCÍA A.I. 2004. Latitudinal variation in tuber production in an aquatic pseudo-annual plant, Potamogeton pectinatus. Aquat. Bot. 79: 51-64.

SCULTHORPE C.D. 1967. The biology of aquatic vascular plants. Edward Arnold, London.

SZMEJA J. 1994a. An individual's status in populations of isoetid species. Aquat. Bot. 48: 203-224.

SZMEJA J. 1994b. Effect of disturbances and interspecific competition in isoetid populations. Aquat. Bot. 48: 225-238.

SZMEJA J. 2006. A guide to the study of aquatic vegetation. Wyd. UG, Gdańsk, 467 (in Polish).
SZMEJA J., BOCIĄG K. 2004. The disintegration of populations of underwaterplants in soft water lakes enriched with acidic organic matter. Acta Soc. Bot. Pol. 73: 165-173.

SZMEJA J., BAZYDŁO E. 2005. The effect of water conditions on the phenology and age structure of Luronium natans (L.) Raf. populations. Acta Soc. Bot. Pol. 74: 253-262.

SZMEJA J., GAŁKA A. 2008. Phenotypic responses to water flow and wave exposure in aquatic plants. Acta Soc. Bot. Pol. 77: 59-65.

WALTER H., LIETH H. 1967. Klimadiagram-Weltatlas, VEB Gustav Fischer Verlag, Jena.

WALTER H., HARNICKELL E., MUELLER-DOMBOIS D. 1975. Klima-Diagramm Karten der einzelnen Kontinente und die ökologische Klimagliederung der Erde. G. Fischer, Stuttgart.

WALTER H., STRAKA H. 1970. Arealkunde. Floristisch-historische Geobotanik, 2. Aufl. E. Ulmer, Stuttgart.

WETZEL R.G. 2001. Limnology. Lake and River Ecosystems. 3 ed. Academic Press, San Diego-San Francisco-New York-Boston-London-Sydney-Tokyo. 